\title{
Methods of financing of projects and oil and gas projects of common priority (A Case Study of Pars Oil \& Gas Company) and comparison with Qatar and provide the optimal solution
}

\author{
I. Azarkish*, \\ Master degree (M.A) in Business Management from Shahid Behesti University, Tehran, Iran. \\ *Corresponding Author email: leiliazar50@gmail.com
}

\section{T.Khalili Varnamkhasti,}

Master degree (M.A) in Financing Management from Semnan Science and Research Branch, Islamic Azad University, Semnan, Iran

Email: tahmeniehkhalili2@yahoo.com

\begin{abstract}
In this research, we consider the financial procedure of projects plan in the field of oil \& gas to make a Comparison between Qatar \& Iran, regarding the amount of investment \& gas and oil production in the south pars common field. Accordingly, we're going to provide optimal solution to promote financing of projects \& performance\& plans in the area of oil \& gas in the POGC. Through library studies, we gathered information regarding the amount of investment \& removal in the common field in which two countries (Iran \& Qatar) have down in the south pars. Also, by using of research literature which has been written of updated financing procedure, we have provided a questionnaire in which the validity of it has been examined by CRONBACH's alpha. Regarding subject of research, we select a statistic society from senior managers, intermediate managers, operations, head of department and senior experts and experts (knowledge contracts and financing of oil and gas projects) of national Iranian oil company (NIOC) \& PARS oil \& gas company (POGC) .the results acquired through library studies show that the amount of investment by Iran is 49.129 USD billion \& Qatar is 109.40 USD billion; there for, the amount of removal gas by Iran is 357 million cubic meters \& Qatar is 597 million cubic meters per day . Accordingly Qatar oil production is 300,000 Barrel per day but The Iranian oil layers still not reached the production stage. The analysis of the responses received, it is clearly show that PSA (production sharing agreement) is a suitable procedure to expedite increasing of removal / production in common fields.
\end{abstract}

\section{Key words:}

New Pertaining to Concession, Buy back, Production sharing agreement \& Participation in Investment.

\section{Introduction}

There are about 100 oil \& gas fields in Iran, among which 28 are in common with neighbor countries like Iraq, Kuwait, KSA, Qatar, UAE, and Oman etc. Among all 28 fields there are 18 oil fields, 4 gas fields and 6 fields include oil \& gas resources.

National Iranian Oil Company (NIOC) has already launched production from 10 common oil \& gas fields, but there are still 18 sources left suspended. These 28 sources include 15 off-shore sources and 13 on-shore ones. Iraq with 12 common sources with Iran is the first neighbor country with common Hydrocarboric sources. After that UAE appears with 7 common sources, and then KSA with 4, next Oman \& Qatar with 2 sources and finally 1 common Hydrocarboric source with Kuwait \& Turkmenistan.

In this research we are focused on South Pars common Oil \& Gas field between Iran and Qatar, and we are planning to compare the level of investment as well as level of production of both parties from this field and eventually proposing optimized solutions to have a faster exploitation.

\section{1) Pars Oil \& Gas Company and Qatar Petroleum (QP) with Priority of South Pars Common Oil \& Gas Fields (North Dome)}

South Pars Field (Iran) and North Dome (Qatar) is one of the Natural Gas fields in Persian Gulf. This common field between Iran \& Qatar is considered as the biggest gas field in the whole world.


gas and 50 billion barrels $\left(7.9\right.$ Billion $\left.\mathrm{M}^{3}\right)$ compacted natural gas. This field covers a land of $9700 \mathrm{~K}^{2}$, from this dimension there are $3700 \mathrm{~K}^{2}$ within Iran seas and $6000 \mathrm{~K}^{2}$ within Qatar seas in North Dome.

1.2. South Pars Gas Field: The gas resources of this field is 14 trillion $\mathrm{M}^{3}$ in addition with 18 billion barrels gas liquids which covers $7.5 \%$ of whole world's gas resources and almost half of the country's gas resources (Dehghani, 2014).

There are currently professional plans ongoing in order to develop the phase 24 for producing 823 Million $\mathrm{M}^{3}$ gas daily and also 35 thousand barrels of oil. Below you can find a summary of these phases in table No. 1 (www.pogc.ir): 
Table No. 1 - Oil \& Gas Projects Executive Contractors - Project Starting time and Ending time

\begin{tabular}{|c|c|c|c|c|c|c|c|}
\hline Project Name & \multicolumn{5}{|c|}{ Rate of Co-Ownership \& Contractors } & $\begin{array}{l}\text { Start } \\
\text { Time }\end{array}$ & $\begin{array}{l}\text { Production } \\
\text { Date }\end{array}$ \\
\hline Oil Layers & \multicolumn{5}{|l|}{ Petro Iran } & 2004 & \\
\hline Phase 1 & \multicolumn{5}{|l|}{ Petropars } & 1997 & 2004 \\
\hline Phases 2 \& 3 & Total - $40 \%$ & \multicolumn{2}{|c|}{$\begin{array}{l}\text { Gas Prom - } \\
30 \%\end{array}$} & \multicolumn{2}{|c|}{ Petronas - $30 \%$} & 1997 & 2002 \\
\hline Phases $4 \& 5$ & Eni $-60 \%$ & \multicolumn{2}{|c|}{$\begin{array}{l}\text { Petropars - } \\
20 \%\end{array}$} & \multicolumn{2}{|c|}{ Nico $-20 \%$} & 2000 & 2005 \\
\hline Phases $6,7 \& 8$ & \multicolumn{2}{|l|}{ Petro Pars } & \multicolumn{3}{|c|}{ Stat Oil } & 2000 & 2009 \\
\hline Phases $9 \& 10$ & GS Korea & & & & & 2002 & 2008 \\
\hline Phase 11 & \multicolumn{5}{|l|}{-} & - & - \\
\hline Phase 12 & \multicolumn{5}{|l|}{ Petropars } & 2009 & 2014 \\
\hline Phase 13 & Petro Paydar & \multicolumn{2}{|c|}{ Sadra } & \multicolumn{2}{|c|}{ Mapna } & 2010 & - \\
\hline Phase 14 & Eidro & & & $\begin{array}{l}\text { Mpan } \\
\text { a }\end{array}$ & Arak Machienries & 2010 & - \\
\hline Phases $15 \& 16$ & Khatam-ol Anbia & $\begin{array}{l}\text { ISO } \\
\text { ICO }\end{array}$ & $\begin{array}{l}\mathrm{SA} \\
\mathrm{F}\end{array}$ & \multicolumn{2}{|c|}{ Dana Energy } & 2006 & - \\
\hline Phases $17 \& 18$ & Eidro & \multicolumn{2}{|c|}{$\begin{array}{l}\text { Tasisat } \\
\text { Daryaee }\end{array}$} & \multicolumn{2}{|c|}{ Mohandesi va Sanaye Naft } & 2006 & - \\
\hline Phase 19 & \multicolumn{5}{|l|}{ Petro Pars } & 2004 & - \\
\hline Phase $20 \& 21$ & & 2010 & - \\
\hline Phase 22, 23 \& 24 & \multicolumn{2}{|l|}{ Petro Sina Arya } & \multicolumn{3}{|c|}{ Sadra } & 2010 & - \\
\hline
\end{tabular}

Qatar Petroleum: Qatar Petroleum (QP) is the Qatar official Oil Company which is one of the biggest Oil Companies in the world regarding ownership of Gas \& Oil resources. Qatar Petroleum (QP) is playing a more significant role in natural gas industry comparing to oil and this company is leading it in details as well as whole aspects. Qatar, in development of its natural gas industry, has concentrated on huge unified projects related to LNG exports and also on industries in which natural gas is used as feeder; hence big international companies with experiences and technologies in working in huge unified projects, such as Exon Mobil, Shell, Total, etc... has been involved in development movements in Qatar by signing production co-ownership contracts (PSA). Qatar Petroleum has awarded the projects of Natural Liquid Gas to Qatar Gas and Ra's-al-fan Companies, which owns the majority of their shares. Table No. 2 is related to Qatar's oil \& gas projects which have been operated or under process, on the common field:( Adibi, 2007)

TABLE No. 2

\begin{tabular}{|c|c|c|c|c|c|c|c|c|c|}
\hline \multicolumn{10}{|c|}{ Table 2. Executive Contractors in Qatar Oil \& Gas Projects - Starting Date/Ending Date } \\
\hline \multicolumn{2}{|c|}{ Project Name } & Phase & \multicolumn{5}{|c|}{ Rate of Co-Ownership \& Contractors } & $\begin{array}{l}\text { Start } \\
\text { Time }\end{array}$ & $\begin{array}{c}\text { Production } \\
\text { Year }\end{array}$ \\
\hline \multicolumn{3}{|c|}{ Alshahin oil \& Gas Field } & \multicolumn{5}{|c|}{ Maersk (Denmark) } & 1984 & 1991 \\
\hline \multirow{6}{*}{ 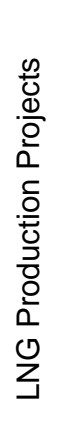 } & \multirow{3}{*}{$\begin{array}{l}\text { Qatar } \\
\text { Gas } 1\end{array}$} & 1 & \multirow{3}{*}{$\begin{array}{c}\text { Qatar Oil- } \\
65 \%\end{array}$} & \multirow{3}{*}{$\begin{array}{c}\text { Exon } \\
\text { Mobil- } \\
10 \%\end{array}$} & \multirow{3}{*}{$\begin{array}{l}\text { Total- } \\
10 \%\end{array}$} & \multirow{3}{*}{$\begin{array}{c}\text { Mitsoni- } \\
7.5 \%\end{array}$} & \multirow{3}{*}{$\begin{array}{c}\text { Marbonni- } \\
7.5 \%\end{array}$} & 1991 & \multirow{3}{*}{1997} \\
\hline & & 2 & & & & & & 1991 & \\
\hline & & 3 & & & & & & 1991 & \\
\hline & \multirow{2}{*}{$\begin{array}{l}\text { Qatar } \\
\text { Gas } 2\end{array}$} & 4 & $\begin{array}{c}\text { Qatar Oil- } \\
70 \%\end{array}$ & \multicolumn{4}{|c|}{ Exon Mobil-30\% } & \multirow{2}{*}{2004} & 2008 \\
\hline & & 5 & $\begin{array}{c}\text { Qatar Oil- } \\
65 \%\end{array}$ & \multicolumn{2}{|c|}{ Exon Mobil-18.3\% } & \multicolumn{2}{|c|}{ Total-16.7\% } & & 2009 \\
\hline & $\begin{array}{l}\text { Qatar } \\
\text { Gas } 3\end{array}$ & 6 & $\begin{array}{c}\text { Qatar Oil- } \\
68.5 \%\end{array}$ & \multicolumn{2}{|c|}{ Conoco Philips-30\% } & \multicolumn{2}{|c|}{ Mitsobishi Japan-1.5\% } & 2005 & 2010 \\
\hline
\end{tabular}




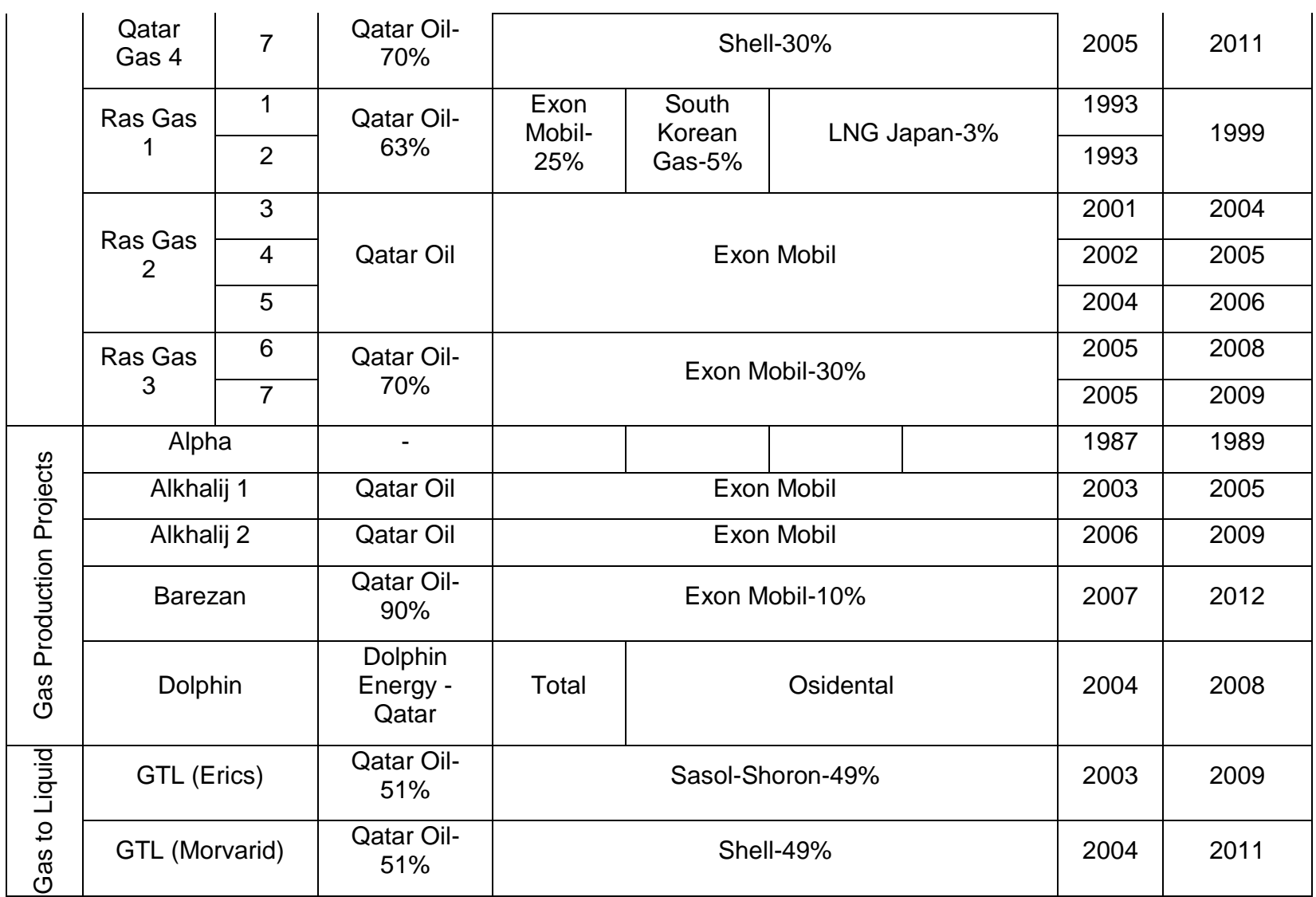

\section{2) Financing Systems}

The project financing, is a shorting method to do a long term financing, which is used in large projects based on financial engineering only based on shorting for the liquidity circuit that is resulted from the project; therefore one of the projects success elements is having access to adequate and in-time financial sources, proper management of sources and the optimum utilization. The significance of availability of proper financial sources is that without them, the project wouldn't be accomplished or at least wouldn't achieve the pre-defined objectives.( Edward, 2008)

Considering the type of Oil contracts and their financing are entirely inter-related, we are demanded to study the oil contracts. Generally the oil contracts are subcategorized in to different types like 'concessive', 'Production Sharing', 'Participation in Investment', 'Subcontracting', 'Services Procurement', and 'Buyback', ...

\subsection{Concession Contracts}

Concession Contract is the first contractual pattern used for exploitation of oil resources. This pattern of contract has experienced two totally different types, a) The 'Traditional Concession Contracts' which had been used from early $20^{\text {th }}$ century until the mid of the century, b) The 'New Concession Contracts' which has been used since the $50 \mathrm{~s}$ in $20^{\text {th }}$ century.

In such contracts the host country would submit the exclusive exploitation from its specified resources for the contract period, to an out sourcing company, and in instead it would receive royalty/bonus and Tax.

New Concession Contracts have kept the first scheme of traditional type of contracts; but they have faced important changes comparing the old ones including commitment of Out-Sourcing companies' to keep social, political and economic benefits of the developing countries which were neglected in traditional type of contracts.( Amri, 2014)

\subsection{Production Sharing Agreements}

Such contracts are signed between government and an oil company or a consortium of technically qualified companies. According to such contracts the second party as contractor would receive from the government, the exclusive permission of exploration and production of oil in a certain period and location. Contractor, undertaking project risks, would provide financial and technical services within activities like exploration, development, production and marketing, instead the government would commit to pay back a certain share of production to compensate the risks and the services. The contract duration, likewise concession contracts, in case of no/little oil findings, would last from 5 to 6 years, but in case of oil finding it would be between 25 to 40 years. (Gholipoor, 2013)

\subsection{Participation in Investment Contracts}

These type of contracts are a developed type of participative contracts, based on which the country of oil sources, would act like a partner in benefits and probable risks of the project. The government's share would be paid directly of from 


\section{ISSN $2321-1091$ \\ Volume 11 Number 2 \\ JOURNAL OF SOCIAL SCIENCE RESEARCH}

assigning a share of production to the financer company. In such contract, the host country, in addition to tax, would receive a certain percentage of the actual benefit of investment.

\subsection{Buy Back Contracts}

Current Buy-Back Contracts in oil \& gas and petrochemical industries of the world, have been appeared not later than 3 decades ago from East European countries. In this contract all financial resources of the project including exploration, development, production and reconstruction of the resources are provided by the financer company. When the project reaches to production level, the country would pay back the actual investment and its benefit to the contractor. After completion of executive operation of the project (Setting-up \& Production), the owner country would take the responsibility of controlling the operation, and will be the sponsor of project's financial needs, and the contractor would have no ownership share. You can refer to contracts of phases 1 8, 12, $19 \ldots$ from South Pars as similar type of contracts.

\section{3) External Fundraising Obstacles and Limitations in Oil \& Gas Industry}

The obstacle and limitations which affect the external fundraising in oil \& gas industry can be categorized in 3 groups of Legal, Economic and Political limitations.

3.1. Legal Limitations: By Legal limitations in Oil \& Gas industry, we mean Constitution, Oil Laws, Economic/Social and Cultural Development Regulations, Annual Budgeting Laws and Executive Laws and Regulations, among which we can refer to articles 152, 139, 153, 125, 83, 81, 80, 77, 45 and 44 of Constitution(Constitution 1989) or article No. 2 of Oil Laws.( Ghasemian, 2011)

3.2. Economic Limitations: Regarding Economic obstacles \& limitations in external fundraising, the risk index of countries is a significant issue for external financers to invest in a different country, and Iran in the ranking released in 2016 by Development \& Economic Collaboration Org., has devaluated his risk index from 7 to 6 . Among 201 studied countries, there are 37 countries with risk index of 6, among which you can name Albania, Angola, Cambodia, Congo, Ecuador, Egypt, Ethiopia, Ghana, Kazakhstan, Kenia, Nepal, Nigeria and Zambia and also Iran's place among studied 201-country is really undesirable.( Gholipoor, 2013)

3.3. Political Limitations: From mid 90s, financer, especially in Oil \& Gas fields, have found Iran's political situation stable and accordingly they expressed their wish to invest in Iran. Iran, relatively could sign contracts of Oil \& Gas sources development with Total (France) and Petronas (Malaysia). In recent years considering the conflict raised for Iran's Nuclear Energy movements, and due to the sanctions against Iran, we can observe their negative impacts on external fundraising in Iran, especially in upstream oil \& gas industries. (Gholipoor, 2013)

\section{4) Research Methodology}

4.1. Research Methodology \& Objective: This research in terms of objectivity is practical and in term of Methodology is Descriptive and also in term of research project is surveying. For research literature the Library methodology is used, and in order to achieving required data, the surveying method (using questioners) have been utilized, meanwhile in order to collect data about Qatar methods to finance and invest in oil \& gas industry, the library methodology has been used (websites, Books and Certified Journals). The objective of this research is to provide an optimized solution to fundraise the projects and plans in oil \& gas industry in common fields. In this research, 'optimized solution' is a solution leading to increase the speed and the level of production from common oil \& gas sources.

\subsection{Research Question:}

a) What is the rate of investment/reimbursement on Oil \& Gas common fields between Iran \& Qatar in South Pars (North Dome)?

b) Which method of financing and fundraising among below listed ones, considering the common fields, would fall in priority in Iran Oil \& Gas industry?

1. New Concession; 2. Buyback; 3. Production Sharing; 4. Participation in Investment

4.3. Statistical Society \& Sample Case: The statistical society of the research consists of 69 top managers, middle manager, operative manager, senior experts and specialized experts of NIOC and Pars Oil \& Gas Co. (acquaintance with contracts methods of fundraising for projects).

4.4. Methods and Tools of Collecting Data: Acquiring the latest data required regarding the researches have been done about the subject were only applicable through studying publications, books and articles for which we have tried to be as accurate as it was possible. To collect the data required in order to provide optimized solutions, the questionnaires have been used.

4.5. Stability \& Validity of Research Tools: To guarantee the stability of the questionnaire, the Cronbach Alfa Testing method was used, results driven from which for validation of questions related to methods of financing for mentioned contracts were as: New Concessive Contracts (0.879), Buyback Contracts (0.863), Production Sharing Agreements (0.911) and Participation in Investment Contracts (0.879). Considering that the minimum required score for validation of a question was 0.7 ; therefore all questions were certified. 
4.6. Data Analysis Methods: Data analysis methods were as 'statistical', 'Research base' and 'Computer base' which are described as below:

\subsubsection{Statistical Methods:}

a) Descriptive Statistical Methods: This method was used to describe the demographic variables of the statistical society as well as summarizing the surveying results of statistical society.

b) Analytical Methods: This method is used to analyze and deduct the research findings. These methods are 'Rating Variance Test with Croscal Valis Criteria' and 'Spearman Rating Correlation Coefficient'.

4.6.2. Multi-Criteria Decision Making Process: TOPSIS Technique is Prioritizing based on similarities with the ideal method. This technique can be used to rank and compare different options, and select the best option among them; it also can be used to find the level of difference between options as well as classifying them. According to this method, the best option is the closest solution to the ideal solution and the worst one is the one farthest to the ideal solution. To weight the criteria the 'Shannon Entropy' approach was used.

4.7. Research Model: Overall frame of the research model is as Diagram No. 1, in which each of the financing methods would be tested with 11 criteria, then they are prioritized by TOPSIS Decision Making method.

Diagram No. 1

financing methods Calculation\& analyzes

criteria

\begin{tabular}{|c|c|c|c|}
\hline & \multirow{11}{*}{$\begin{array}{l}\text { TOPSIS Decision } \\
\text { Making Method }\end{array}$} & 1 & Acceleration in increasing production \\
\hline & & 2 & Keeping Production Protected \\
\hline & & 3 & Attraction for External Fundraising \\
\hline New Concessive & & 4 & Acceleration in Technology Sharing \\
\hline Buyback & & 5 & $\begin{array}{l}\text { Level of association and enhancement of local } \\
\text { contractors }\end{array}$ \\
\hline $\begin{array}{l}\text { Production Sharing } \\
\text { Agreements }\end{array}$ & & 6 & Necessity of revising the financing methods \\
\hline $\begin{array}{l}\text { Participation in } \\
\text { Investment }\end{array}$ & & 7 & $\begin{array}{l}\text { Revising the regulations of production from } \\
\text { common fields }\end{array}$ \\
\hline & & 8 & Appropriate cultural field for external fundraising \\
\hline & & 9 & $\begin{array}{l}\text { Impact of fluctuations of Oil \& Gas global price } \\
\text { rate }\end{array}$ \\
\hline & & 10 & Economic advantages \\
\hline & & 11 & Risks for financer \\
\hline
\end{tabular}

4.8. Computer Base Methods and Prioritizing Options: Excel, SPSS and TOPSIS softwares were used in this research to analyze the data and to prioritize the decision making methods.

\section{5) Ideas Compatibility Analysis}

In studying the impact of Demographic Variables on the way participants answering questions, the Rating Variance Test with Croscal Valis Criteria and the Spearman Rating Correlation Coefficient were used. The analysis of the ideas compatibility, based on Level of Education, Field of Study, Organizational position and working experience is as below:

5.1. Precise study of participants ideas in 3 education levels of PhD., Master and Bachelor has revealed that among 38 questions answered from 44 given questions, there has been a direct relevance between level of education and intensity of the allocated variables in questions. That's to say those with higher levels of education have been affected more, but there has been no direct impact between 7 mentioned options.

5.2. Reviewing the questions reveals that 36 of the research questions have been affected by the level of the education of the participants, that means the compatibility of the participants with the questions were different and those with relevant educational background to financing methods have been more affected and considering the education field, options with more impacts were selected by them.

5.3. Reviewing the questions shows that for 15 questions, participants, regardless their organizational position, all were consensus and for other 29 remaining questions they had different compatibilities. It is noticed that, in assessments done by participants who were in 5 different levels of organizational positions (Experts, Senior Experts, Managers, Senior \& Middle Operational Managers,) those with higher rankings, have selected those options with higher impacts. 
5.4. In demographic variable related to work experience, according to quantitative impact of this variable on participants responding, the Spearman rating correlation coefficient criteria has been used. Reviewing the impact of the participants working experience on their responding, reveals that working experience has no major impact on answering and almost all answers were similar in 9 questions, and in other questions the impact of difference in working experience was noticeable.

\section{6) Research Findings}

\subsection{Research Library Findings}

Research findings are compared based on the amount and type of investments (Projects Financing) in both Iran \& Qatar countries and also the rate of production in these two countries from common oil \& gas field.

\section{a) Amount and type of financing in Iran \& Qatar for Common Field}

The amount of financing in Iran (by Pars Oil \& Gas Co.) in South Pars field according to table \#4 is totally 49.129 billion USD (Local source is 29.754 billion USD and the Buyback is equal to 19.375 billion USD), among this 297 million USD is for common oil field and 19.86 billion USD is for finalized phases of 1 to 10 and 12; and 28.99 billion USD is for other ongoing phases. Iran is intended to spend additional 30 billion USD to accomplish the ongoing phases.

The amount of financing in Qatar in North Dome filed according to table \#5 is totally 109.40 billion USD (Participation in Production) among which 6 billion USD is invested in common field and 55.10 billion USD in liquid natural gas production projects and 23.30 billion USD in gas production projects and finally 25 billion USD in gas to liquid conversion projects.

Table 4_Iran Investment in Common Oil \& Gas Field (Pars Oil \& Gas Co.)

\begin{tabular}{|c|c|c|c|}
\hline \multicolumn{2}{|c|}{ Project Name } & \multirow{2}{*}{$\begin{array}{c}\begin{array}{c}\text { Billion } \\
\text { USD }\end{array} \\
0.279\end{array}$} & \multirow{2}{*}{$\begin{array}{c}\begin{array}{c}\text { Financing } \\
\text { Method }\end{array} \\
\text { Local Sources }\end{array}$} \\
\hline \multirow{15}{*}{$\begin{array}{l}\text { Gas } \\
\text { Production } \\
\text { Projects }\end{array}$} & Oil Layers & & \\
\hline & Phase 1 & \multirow{6}{*}{19.86} & \multirow{4}{*}{ Buyback } \\
\hline & Phases $2 \& 3$ & & \\
\hline & Phases $4 \& 5$ & & \\
\hline & Phases 6,7\&8 & & \\
\hline & Phases $9 \& 10$ & & Local Sources \\
\hline & Phase 12 & & Buyback \\
\hline & Phase 11 & \multirow{8}{*}{28.99} & Local Sources \\
\hline & Phase 13 & & \multirow{4}{*}{ Local Sources } \\
\hline & Phase 14 & & \\
\hline & Phases 15\&16 & & \\
\hline & Phases 17\&18 & & \\
\hline & Phase 19 & & Buyback \\
\hline & Phases $20 \& 21$ & & \multirow[b]{2}{*}{ Local Sources } \\
\hline & $\begin{array}{l}\text { Phases } \\
22,23 \& 24\end{array}$ & & \\
\hline \multicolumn{2}{|c|}{ Total Financing Amount } & \multicolumn{2}{|r|}{49.129} \\
\hline
\end{tabular}

Table 5_Qatar Investment in Common Oil \& Gas Field

\begin{tabular}{|c|c|c|c|}
\hline \multicolumn{2}{|c|}{ Project Name } & $\begin{array}{l}\text { Billion } \\
\text { USD }\end{array}$ & $\begin{array}{c}\text { Financing } \\
\text { Method }\end{array}$ \\
\hline \multicolumn{2}{|c|}{ Alshahin Oil Field } & 6 & \multirow{14}{*}{$\begin{array}{c}\text { Production } \\
\text { Sharing }\end{array}$} \\
\hline \multirow{6}{*}{$\begin{array}{l}\text { LNG } \\
\text { Production } \\
\text { Projects }\end{array}$} & Qatar Gas 1,2,3 & \multirow{6}{*}{55.1} & \\
\hline & Qatar Gas 4,5 & & \\
\hline & Qatar Gas 6,7 & & \\
\hline & Ras Gas 1,2 & & \\
\hline & Ras Gas 3,4,5 & & \\
\hline & Ras Gas 6,7 & & \\
\hline \multirow{5}{*}{$\begin{array}{c}\text { Gas } \\
\text { Production } \\
\text { Projects }\end{array}$} & Alpha & 1.2 & \\
\hline & Alkhalij 1 & \multirow{4}{*}{22.1} & \\
\hline & Alkhalij 2 & & \\
\hline & Barzan & & \\
\hline & Dolphin & & \\
\hline \multirow{2}{*}{$\begin{array}{l}\text { Gas to } \\
\text { Liquid }\end{array}$} & GTL (Erix) & \multirow{2}{*}{25} & \\
\hline & GTL (Morvarid) & & \\
\hline \multicolumn{2}{|c|}{ Total Financing Amount } & \multicolumn{2}{|c|}{109.4} \\
\hline
\end{tabular}

(Khajavi, 2014-(MEES Al-Shaheen,. 2013-2011-2014www.qatargas.com- www.qp.com.qa -Qatar Barzan gas2011www.rasgas.com-www.raslaffan.qp.qa)

(Dehghani, 2014-www.pogc.ir- Abbas zadeh, 2014)

In general the total financing of Iran \& Qatar in common oil \& gas field is respectively 49.129 billion USD and 109.40 billion USD.

\section{b) Amount of Production in Iran \& Qatar from Common Field}

According to table \#6, the rate of daily gas production of Iran from South Pars field, is currently 357 million $\mathrm{M}^{3}$, by utilizing the ongoing phases this rate of daily production can reach up to 800 million $\mathrm{M}^{3}$ (currently there is no oil produced from this field by Iran) 
According to table \#7, the rate of daily gas production of Qatar from North Dome field, is currently 597 million $\mathrm{M}^{3}$ and 300 thousand oil barrels per day. Some part of this gas production will be transferred to 170 thousand barrels liquid products in two TLRX \& Pearl (Morvarid) projects.

Table 6_Iran Production Rate in Common Oil \& Gas Field (Pars Oil \& Gas Co.)

Figures are in Million M3

\begin{tabular}{|c|c|c|c|}
\hline \multicolumn{2}{|c|}{ Project Name } & \multirow{2}{*}{$\begin{array}{c}\text { Capacity } \\
35,000 \\
\text { Barrel } \\
\text { Per Day }\end{array}$} & \multirow{2}{*}{$\begin{array}{c}\text { Production } \\
-\end{array}$} \\
\hline Oil & Oil Layers & & \\
\hline \multirow{14}{*}{$\begin{array}{c}\text { Gas } \\
\text { Production } \\
\text { Projects }\end{array}$} & Phase 1 & 28 & 28 \\
\hline & $\begin{array}{c}\text { Phases } \\
2 \& 3\end{array}$ & 56 & 56 \\
\hline & $\begin{array}{c}\text { Phases } \\
4 \& 5\end{array}$ & 56 & 56 \\
\hline & $\begin{array}{c}\text { Phases } \\
6,7 \& 8\end{array}$ & 104 & 104 \\
\hline & $\begin{array}{c}\text { Phases } \\
9 \& 10\end{array}$ & 56 & 56 \\
\hline & Phase 12 & 84 & 57 \\
\hline & Phase 11 & 56 & - \\
\hline & Phase 13 & 56.6 & - \\
\hline & Phase 14 & 56.6 & - \\
\hline & $\begin{array}{c}\text { Phases } \\
15 \& 16\end{array}$ & 56.6 & - \\
\hline & $\begin{array}{c}\text { Phases } \\
17 \& 18\end{array}$ & 50 & - \\
\hline & Phase 19 & 50 & - \\
\hline & $\begin{array}{l}\text { Phases } \\
20 \& 21\end{array}$ & 56.6 & - \\
\hline & $\begin{array}{c}\text { Phases } \\
22,23 \& 24\end{array}$ & 56.6 & - \\
\hline \multicolumn{2}{|c|}{ Total } & 823 & 357 \\
\hline
\end{tabular}

(www.pogc.ir- Abbas zadeh, 2014)
Table 7_Qatar Production Rate in Common Oil \& Gas Field

\begin{tabular}{|c|c|c|c|}
\hline \multicolumn{4}{|c|}{ Figures are in Million M3 } \\
\hline \multicolumn{2}{|c|}{ Project Name } & \multirow{2}{*}{$\begin{array}{c}\text { Capacity } \\
300,000 \\
\text { Barrels } \\
\text { PD }\end{array}$} & \multirow{2}{*}{$\begin{array}{c}\text { Production } \\
\\
300,000 \\
\text { Barrels PD }\end{array}$} \\
\hline Oil & $\begin{array}{l}\text { Alshahin Oil } \\
\text { field }\end{array}$ & & \\
\hline \multirow{6}{*}{$\begin{array}{l}\text { LNG Production } \\
\text { Projects }\end{array}$} & $\begin{array}{c}\text { Qatar Gas } \\
1,2,3\end{array}$ & 45 & 46 \\
\hline & $\begin{array}{c}\text { Qatar Gas } \\
4,5\end{array}$ & 82 & 81 \\
\hline & $\begin{array}{c}\text { Qatar Gas } \\
6,7\end{array}$ & 80 & 79.2 \\
\hline & Ras Gas 1,2 & 31 & 31.5 \\
\hline & $\begin{array}{c}\text { Ras Gas } \\
3,4,5\end{array}$ & 90 & 90.8 \\
\hline & Ras Gas 6,7 & 80 & 78.4 \\
\hline \multirow{5}{*}{$\begin{array}{l}\text { Gas Production } \\
\text { Projects }\end{array}$} & Alpha & 23 & 20.8 \\
\hline & Alkhalij 1 & 24 & 24 \\
\hline & Alkhalij 2 & 40 & 40 \\
\hline & Barzan & 48 & 48 \\
\hline & Dolphin & 70 & 57.6 \\
\hline \multirow{2}{*}{ Gas to Liquid } & GTL (Erix) & Alkhalij & $\begin{array}{c}30,000 \\
\text { Barrels PD }\end{array}$ \\
\hline & $\begin{array}{c}\text { GTL } \\
\text { (Morvarid) }\end{array}$ & Alkhalij & $\begin{array}{c}140,000 \\
\text { Barrels PD }\end{array}$ \\
\hline \multicolumn{2}{|c|}{ Total } & 613 & 597.3 \\
\hline
\end{tabular}

(Khajavi, 2014- Dokhani, 2009 -MEES Al-Shaheen,. 2013-2011-2014www.qatargas.com- www.qp.com.qa -Qatar Barzan gas2011www.rasgas.com-www.raslaffan.qp.qa)


gas per day and the rate of oil production for Qatar is 300 thousand barrel per day, and the oil projects of Iran hasn't arrived to production level yet.

6.2. Research Surveying Findings: The statistical society has been under study in analyzing the surveying findings for which questionnaires were dispatched among them and there were 56 people who filled them.

\section{7) Decision Making Process}

This process has been done by TOPSIS Technique and has been weighted by Shannon Entropy methodology. At the beginning of the stage the options and the criteria have been clarified and the Decision Matrix was set up. This Matrix consists of 4 options and 11 criteria (Diagram \#1). 
To complete the figures on decision matrix the experts' comments were used and according to qualitative data range axis, questionnaires were completed by 'Vey much', 'Much', 'Average', 'Little' and 'Very little'. And the standard spectrometer of qualitative data was used to quantify and count the data.

Ranking the 4 options with 11 common criteria: At first the Decision Matrix data by 4 options and 11 criteria has been prepared which is based on the average of the statistical society comments, as elaborated in table \#8.

\begin{tabular}{|c|c|c|c|c|c|c|c|c|c|c|c|}
\hline \multicolumn{12}{|c|}{ Table 8_Decision Making Matrix with 4 Options \& 11 Criteria } \\
\hline Options & \multicolumn{11}{|c|}{ Criteria } \\
\hline $\begin{array}{l}\text { Financing } \\
\text { Methods }\end{array}$ & 1 & 2 & 3 & 4 & 5 & 6 & 7 & 8 & 9 & 10 & 11 \\
\hline New Concessive & $6 / 523$ & $6 / 237$ & $7 / 857$ & $6 / 013$ & $3 / 679$ & $6 / 214$ & $7 / 643$ & $5 / 633$ & $6 / 250$ & $5 / 179$ & $5 / 643$ \\
\hline Buyback & $5 / 893$ & $5 / 036$ & $5 / 286$ & $5 / 571$ & $5 / 179$ & $7 / 500$ & $6 / 643$ & $6 / 286$ & $7 / 679$ & $6 / 179$ & $6 / 536$ \\
\hline $\begin{array}{l}\text { Production } \\
\text { Sharing }\end{array}$ & $7 / 464$ & $6 / 250$ & $7 / 857$ & $6 / 214$ & $5 / 250$ & $6 / 607$ & $7 / 786$ & $5 / 750$ & $6 / 964$ & $6 / 571$ & $5 / 071$ \\
\hline $\begin{array}{l}\text { Investment } \\
\text { Participation }\end{array}$ & $5 / 893$ & $6 / 321$ & $6 / 286$ & $5 / 321$ & $5 / 357$ & $5 / 821$ & $7 / 286$ & $4 / 750$ & $6 / 607$ & $6 / 679$ & 4/393 \\
\hline
\end{tabular}

Then we weighted the criteria using Shannon Entropy by utilizing Decision Matrix (table \#9). In weighting using Shannon Entropy, whatever the number of options in each criteria has been placed in a longer period, those criteria would have a higher weight, otherwise it would result vice versa.

\begin{tabular}{|l|c|c|c|c|c|c|c|c|c|c|c|c|}
\hline \multicolumn{1}{|c|}{ Table 9_Criteria Weight with Entropy Shannon } & \multirow{2}{*}{$\begin{array}{c}\text { Total } \\
\text { Weight }\end{array}$} \\
\hline Criteria & 1 & 2 & 3 & 4 & 5 & 6 & 7 & 8 & 9 & 10 & 11 & \multirow{2}{*}{ Writeria Weight } \\
\hline & 0.076 & 0.065 & 0.205 & 0.029 & 0.166 & 0.07 & 0.029 & 0.077 & 0.046 & 0.074 & 0.164 & 1 \\
\hline
\end{tabular}

After getting the decision matrix and the criteria's weight, which are from the significant specifications of decision making by TOPSIS method, unscaled (normalized) and harmonic matrixes were prepared according to table \#10.

\begin{tabular}{|l|c|c|c|c|c|c|c|c|c|c|c|}
\hline \multicolumn{10}{|c|}{ Table 10_Harmonic Matrix with 4 Options \& 11 Criteria } \\
\hline Options & \multicolumn{10}{|c|}{ Criteria } \\
\hline $\begin{array}{l}\text { Financing } \\
\text { Methods }\end{array}$ & 1 & 2 & 3 & 4 & 5 & 6 & 7 & 8 & 9 & 10 & 11 \\
\hline $\begin{array}{l}\text { New } \\
\text { Concessive }\end{array}$ & $0 / 0396$ & $0 / 0337$ & $0 / 1156$ & $0 / 0149$ & $0 / 0615$ & $0 / 0327$ & $0 / 0147$ & $0 / 0381$ & $0 / 0205$ & $0 / 0309$ & $0 / 0839$ \\
\hline Buyback & $0 / 0392$ & $0 / 0272$ & $0 / 0777$ & $0 / 0138$ & $0 / 0865$ & $0 / 0394$ & $0 / 0128$ & $0 / 0425$ & $0 / 0251$ & $0 / 0368$ & $0 / 0972$ \\
\hline $\begin{array}{l}\text { Production } \\
\text { Sharing }\end{array}$ & $0 / 0496$ & $0 / 0337$ & $0 / 1156$ & $0 / 0154$ & $0 / 0877$ & $0 / 0347$ & $0 / 0150$ & $0 / 0389$ & $0 / 0228$ & $0 / 0392$ & $0 / 0754$ \\
\hline $\begin{array}{l}\text { Investment } \\
\text { Participation }\end{array}$ & $0 / 0392$ & $0 / 0341$ & $0 / 0925$ & $0 / 0132$ & $0 / 0895$ & $0 / 0306$ & $0 / 0140$ & $0 / 0321$ & $0 / 0216$ & $0 / 0398$ & $0 / 0653$ \\
\hline
\end{tabular}

Next step is to preparing the best and the worst options in related criteria (Table \#11), in a way that the figure 0.0496 in the best option conveys that in acceleration in production ( $1^{\text {st }}$ Criterion), the best option is 'Production Sharing' ( ${ }^{\text {rd }}$ Option) and the worst option with figure 0.0392 for the first criterion, are $2^{\text {nd }}$ and $4^{\text {th }}$ (Buyback \& Participation in Investment).

\begin{tabular}{|c|c|c|c|c|c|c|c|c|c|c|c|}
\hline \multicolumn{12}{|c|}{ Table 11_Best \& Worst Options in Relative Criteria } \\
\hline \multicolumn{12}{|c|}{ Best Options } \\
\hline Criteria & 1 & 2 & 3 & 4 & 5 & 6 & 7 & 8 & 9 & 10 & 11 \\
\hline Options & $0 / 0496$ & $0 / 0341$ & $0 / 1156$ & 0/0154 & $0 / 0895$ & $0 / 0394$ & 0/0150 & $0 / 0425$ & $0 / 0251$ & $0 / 0398$ & 0/0972 \\
\hline \multicolumn{12}{|c|}{ Worst Options } \\
\hline Criteria & 1 & 2 & 3 & 4 & 5 & 6 & 7 & 8 & 9 & 10 & 11 \\
\hline Options & $0 / 0392$ & $0 / 0272$ & $0 / 0777$ & $0 / 0132$ & $0 / 0615$ & $0 / 0306$ & $0 / 0128$ & $0 / 0321$ & $0 / 0205$ & $0 / 0309$ & $0 / 0653$ \\
\hline
\end{tabular}

Then the distance between the best and the worst options (table \#12), 'Production Sharing' (3rd option) with figures $0.02276 \& 0.05201$ has the shortest distance from the best option, and has the longest distance with the worst option. 


\begin{tabular}{|l|c|c|}
\hline \multicolumn{2}{|c|}{ Table 12_distance between Best \& Worst Options } \\
\hline Options (Finanicng Methods) & Distance from Best Option & Distance from Worst Option \\
\hline New Concessive & $0 / 03507$ & $0 / 04318$ \\
\hline Buyback & $0 / 04016$ & $0 / 04343$ \\
\hline Production Sharing & $0 / 02276$ & $0 / 05021$ \\
\hline Investment Participation & $0 / 04315$ & $0 / 03366$ \\
\hline
\end{tabular}

The last stage is ranking the options based on the proximity factor (tables \#13 \& \#14); therefore 'Production Sharing' has placed in the $1^{\text {st }}$ rank and 'New Concessive' the $2^{\text {nd }}$ rank (table \#14).

\begin{tabular}{|l|c|}
\hline \multicolumn{2}{|c|}{ Table 13_Proximity Factor to the Ideal Option } \\
\hline Options & Proximity Factor \\
\hline New Concessive & $0 / 5518$ \\
\hline Buyback & $0 / 5196$ \\
\hline Production Sharing & $0 / 6880$ \\
\hline Investment Participation & $0 / 4383$ \\
\hline
\end{tabular}

\begin{tabular}{|l|c|}
\hline \multicolumn{2}{|c|}{ Table 14_Rating } \\
\hline Options (Financing Methods) & Rating \\
\hline New Concessive & 1 \\
\hline Buyback & 2 \\
\hline Production Sharing & 3 \\
\hline Investment Participation & 4 \\
\hline
\end{tabular}

\section{8) Conclusion}

The results driven from this research reveals that Qatar has almost signed all his contracts in 'Production Sharing' way, and with financing over 109.40 billion USD has succeeded to produce 597 M3 gas and 300 thousand oil barrels per day, that's while Iran (Pars Oil \& Gas Co.) has used different ways like 'Buyback' and local financing and at the time being could succeed to finance over 49.125 billion USD and produce 357 million M3 gas per day (excluding the under development phases), but oil layers project in order to produce oil in not accomplished yet; therefore at the time being Qatar it's producing to 240 million M3 gas and 300 thousand barrels of oil per day more than Iran from the common filed and in a aggregative comparison (from the beginning till now) between both countries Qatar's rate of gas production, which has started producing 10years earlier than Iran, is over 1560 billion M3 comparing to 615 billion M3 (2.5 times more than Iran), and regarding the production of oil from the common oil field, after passing 25years, Qatar has already produce over 1 billion barrels of oil while Iran has had no production at all. Hens referring to above mentioned topics Qatar by using 'production sharing' in financing and production from the common field is more successful comparing to Iran which has been using different financing methods like local financing and buyback so the first objective of the research which is focusing on comparison between oil and gas financing and production of Iran and Qatar form the common field, has reached. Researcher, knowing the above subject, by using the research leather has designed the questioner about current oil and gas financing methods, to be able to propose optimized methods to increase the production from the common fields which our country has with Iraq, KSA, Kuwait, Qatar, UAE, and Oman, etc., by distinguishing the week and strong points of these methods.

As mentioned before, the TOPSIS decision making method is based on common criteria; therefore for options which were common in oil 11 criteria have been ranked. The result driven from the research (table 14) is showing that among 4 proposed options for common fields development, production sharing is in the top priority and new concessive a method, buyback, participation in investment would stay in the next priorities.

The production sharing, according to TOPSIS for the best options, among the criteria like acceleration of production, attraction for external funder, acceleration in technology transmission, an revising the countries regulations for the common fields development (criteria 1, 3, 4 and 7), is the best option and buyback among the criteria like necessities of revision in financing methods, preparation on cultural aspects for external fundraising, in pacts of fluctuations of oil and gas global price in such methods and probable risks for external financer (criteria 6, 8, 9 and 11) are the best options. But in options and criteria rating for proposing the best option, 'production sharing' is in the first place therefore it is required to remove all the obstacles on the way of such contracts in the common fields.

According to the acquired results from the proposed answers the second objective of the research which is providing an optimized solution for financing the executive projects in oil and gas in the common fields (Pars oil and gas) has achieved.

\section{9) Productive Proposals:}

According to the results acquired, to have a better production level from common fields, among all methods, the 'Production Sharing' is in priority. To use such contracts and to get more external fundraisings, and respectfully increase in production, it is required to remove all obstacles on its way, such as:

9.1. Revising all trading regulations and official paperwork, which are mentioned as below, in order to prepare the situation to utilize 'Production Sharing' type of contracts: 


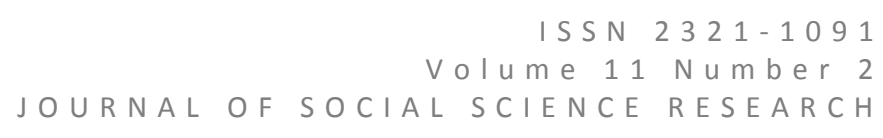

According o the research result, production sharing method, is more effective in acceleration in production from the common fields, and each day of delay in production from the common fields, leads to decreasing Iran's share from those fields. This is necessary that the government, revise the country's regulations. Below some of those regulations are brought:

a) Oil Laws, approved in 1974 and 1987 regarding financing and the tanks ownership

Article \#2 of this law, which is inter related with limitations of utilizing types of contracts certified by officials in NIOC legal departments, conveys "The country's Oil wealth is a public property, and according to the article no 45 from constitution, all equipment and assets and Units Investments at home and abroad by the Ministry of Petroleum and subsidiaries is under Islamic Republic of Iran's control and all installations."

b) The difficult labor laws and regulations governing the relations between employee and employer which stop employers from financing.

c) Social Security Laws: This organization is with highest rates and lowest level of services, and absorbs $30 \%$ of the employee and employer's salary.

\subsection{Reducing the level of risks in financing to increase the attraction for external financers}

To decrease risk of investment we have to remove the economic obstacles such as big size of the government, exchange rate fluctuations, no economic stability, low performance of the ports, weakness in persuasive and promotion policies, no skilled worker, weakness in official regulations and ..., cultural obstacles like the negative point of view regarding relations those overseas, as well as financial dependency with them, Political obstacles like the country's economic sanctions, no political stability in the country, and also security obstacles. And also by exempting financer from tax payment and creating transparency and stability in laws, more attractions for external financers should be created.

\section{0)The research limitations and period:}

10.1. The research period is up to 2014 and all data used here are related to that date.

10.2. The base principals of each research are the data and information gathered and analyzed related to the research. That is obvious that the more complete and accurate data collected by researcher, the outcomes of the research are more reliable and accurate, and the research done will have a higher credibility. On the way doing this research we faced below listed obstacles:

a) Since the financial data of Qatar in the South Pars common filed was not released regularly. To gather and collect such information, the researcher has approached and referred to plenty of resources;

b) The questionnaire's natural limitations;

c) No possibility to trace the reasons why some participants didn't fill up the questionnaires, which could lead to limit the generalization of the driven results;

d) No possibility to fully study the level of accuracy and level of the participants' awareness in responding the questionnaires.

\section{References}

1. Abbas zadeh Behrooz, Studying the status of Pars field development and South Pars Gas field, Stock Brokerage Consultant Firm, 2014

2. Aminzadeh Elham, Aghababaei Dehkordi Peyman, Comparing between financing in oil projects from 'concessive contracts' and 'Production Sharing', 2013

3. Amri Feysal, Shirmardi Dezaki Mohammadreza, 'New concessive Contracts' and the advantages of oil producing countries: An analysis on oil ownership, Observation and management of the host government and contract financial regime, 2014

4. Constitution, approved in 1979 \& revision approved in 1989

5. Ghandia Ali, C.-Y. Cynthia Lin-Oil and gas service contracts around the world: A review-2013

6. Khajavi Ali, Qatar's position in the world's oil \& gas resources and production, and the status of the North Dome development in Qatar, Oil Ministry Deputy Planning, 2014

7. MEES, "Qatar Changes PSAs to JVs, Invests In Al-Shaheen”, 18 Jan. 2013

8. MEES, “Qatar Claims 'GTL World Capital' Status”, 18 Jan. 2013

9. MEES, "Qatar Moratorium Continues As North Field Proves Challenging", 12 Dec. 2011

10. MEES, Qatar gas Signs Flexible UK LNG Deal With Malaysian State Firm PETRONAS", 27 sep2013

11. MEES, Qatar Starts Work On Second Ras Laffan Condensate Refinery", 11 April 2014

12. MEES, Qatar's New Leadership: Impact On QP's And QIA's Strategies”, 14 june2013 
13. Moazemi Mansour, Sadegh Joukar Mohammad, Qatar's Oil \& Gas Report (The US Energy Intelengence Office), No, 5, 2013

14. Momeni Vesalian Houshang, Ghanimifard Hojattolah, Mahmoodi Mohammad, Comparative Study of 'Buyback contracts' and 'Production Sharing Agreements' in upper-stream projects of Iran's Oil \& Gas industry, 2010

15. Naser Gholipoor, Appropriate model for financing development in Iran Oil \& Gas sector and establishing the relevant policy, First edition, 2013

16. Pars Oil \& Gas Co., www.pogc.ir

17. Qatar gas, www.qatargas.com

18. Qatar petroleum, www.qp.com.qa

19. Ramazani Azizollah, Strategies of financing for development of future infrastructures of Gas industry, $24^{\text {th }}$ Global Gas Conference, Argentina, 2009

20. Ras gas Company Limited, www.rasgas.com

21. Ras laffan City, www.raslaffan.qp.qa

22. Reuters, Qatar Barzan gas project to cost \$10bn”, 1 Nov 2011

23. Siamak Adibi, Reviewing the planning in production for South Pars gas field, Econimics \& Energy Magazine, No. 97, 2007

24. Soleyman Ghasemian, Global Trade and natural gas area perspectives in 2035, Exploration \& Production, 2011

25. Tooraj Dehghani, Energy International studying Association, Investing and Financing in Oil \& Gas projects, 2014

26. Vahid Dokhani, Qatar's Pruduction Status from North Dome common field, Exploration \& Production No. 64, 2009

27. Yescomb Edward, Principals of Project financing, Translated by Tahmasb Mazaheri and Amirhossein Tavakili, 2008EIA, "Qatar Country Analysis", January 2014.

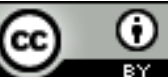

This work is licensed under a Creative Commons Attribution 4.0 International License.

DOI:10.24297/jssr.v11i2.6156 